\title{
KELOMPOK TERNAK BIOENERGI DI DUKUH WUNUT, DESA TANGKISAN, KEC.BAYAN KAB. PURWOREJO JAWA TENGAH
}

\author{
Iswoyo $^{1}$, Harmini², Sri Heranurweni ${ }^{3}$ \\ ${ }^{1}$ Fakultas Teknologi Pertanian,Universitas Semarang \\ ${ }^{2}$ Fakultas Teknik, Universitas Semarang \\ ${ }^{3}$ Fakultas Teknik, Universitas Semarang \\ iswoyo@usm.ac.id, harmini@usm.ac.id,email \\ heranur@usm.ac.id
}

\begin{abstract}
Abstrak
Kelompok ternak Bina Lestari terletak di Dukuh Wunut Desa Tangkisan Bayan Purworejo yang terdiri dari 12 Kepala Keluarga dan mempunyai kandang dua tingkat dengan jumlah sapi 18 ekor. Saat ini telah terbangun satu unit biodigester dengan ukuran $8 \mathrm{~m}^{3}$ oleh kelompok ternak sapi Bina Lestari. Biodigester tersebut saat ini hanya dapat dimanfaatkan untuk $7 \mathrm{KK}$. Berdasarkan hal tersebut perlu dilakukan pengembangan untuk membangun biodigester agar warga yang belum mendapatkan supply biogas dapat teratasi. Permasalahan prioritas yang dihadapi mitra dalam segi sosial, mutu layanan dan kehidupan bermasyarakat adalah masih ada 5 kepala keluarga (KK) yang belum mendapatkan supply biogas untuk memasak sehingga kelima KK masih mengkonsumsi LPG tabung 3 $\mathrm{Kg}$ dan juga masih menggunakan kayu bakar. Limbah biodigester dapat dimanfaatkan untuk diolah menjadi pupuk.

Solusi yang ditawarkan untuk menyelesaikan permasalahan mitra adalah membangun biodigester tambahan dengan kapasitas $12 \mathrm{~m}^{3}$. Kapasitas tersebut dapat digunakan untuk $12 \mathrm{KK}$. Limbah dari biodigester diolah menjadi pupuk. Hasil dari pengabdian ini adalah telah terbangunnya biodigester dengan kapasitas $12 \mathrm{~m}^{3}$ untuk kelompok ternak Bina Lestari Dukuh Wunut Desa Tangkisan Bayan, Purworejo. Sejumlah 12 KK telah dapat memanfaatkan bioenergi tersebut. limbah dari bioenergi dimanfaatkan sebagai pupuk yaitu pupuk cair dan pupuk padat yang digunakan untuk memupuk lahan pertanian.
\end{abstract}

Kata Kunci : Kotoran sapi, Biogas, Biodegester

\section{PENDAHULUAN}

Salah satu sumber energi alternatif yang besar peluangnya untuk dikembangkan pemanfaatannya di Indonesia adalah energi biogas. Gas ini berasal dari berbagai macam limbah organik seperti sampah biomassa, kotoran manusia dan kotoran hewan yang dapat dimanfaatkan menjadi energi melalui proses anaerobic digestion. (DodikPrasetyo, 2016).Energi yang terkandung dalam biogas tergantung dari konsentrasi metana (CH4).Semakin tinggi kandungan metana maka Teknologi Tepat Guna 304 
semakin besar kandungan energi pada biogas (Ismaila O Alabi dkk, 2016).

Biogas adalah gas-gas yang dihasilkan dari proses dekomposisi bahan organik oleh berbagai mikroorganisme secara anaerob. Biogas umumnya terdiri dari metan dan karbondioksida serta beberapa gas lain dengan jumlah yang sangat sedikit seperti hidrogen sulfida, ammonia, nitrogen, dan air(Houdkova et.al., 2008). Biogas merupakan renewable energy yang dapat dijadikan bahan bakar alternatif untuk menggantikan bahan bakar yang berasal dari fosil seperti minyak tanah dan gas alam.Secara umum, semua bahan organik/biomassa dapat digunakan sebagai substrat penghasil biogas selama bahan organik tersebut mengandung karbohidrat, protein, lemak, selulosa, dan hemiselulosa sebagai komponen utamanya (Deublein dan Steinhauser, 2008). Biogas juga sebagai salah satu jenis bioenergi yang didefinisikan sebagai gas yang dilepaskan jika bahan-bahan organik seperti kotoran ternak, kotoran manusia, jerami, sekam dan daun-daun hasil sortiran sayur difermentasi atau mengalami proses metanisasi. Gas metan ini sudah lama digunakan oleh warga Mesir, China, dan Roma kuno untuk dibakar dan digunakan sebagai penghasil panas. Sedangkan proses fermentasi lebih lanjut untuk menghasilkan gas metan ini pertama kali ditemukan oleh Alessandro Volta (1776). Hasil identifikasi gas yang dapat terbakar ini dilakukan oleh Willam Henry pada tahun 1806. Dan Becham (1868) murid Louis Pasteur dan Tappeiner (1882) adalah orang pertama yang memperlihatkan asal mikrobiologis dari pembentukan gas metan (Saija, 2009) .Gas ini berasal dari berbagai macam limbah organik seperti sampah biomassa, kotoran manusia, kotoran hewan dapat dimanfaatkan menjadi energi melalui proses anaerobik digestion Biogas yang terbentuk dapat dijadikan bahan bakar karena mengandung gas metan $\left(\mathrm{CH}_{4}\right)$ dalam persentase yang cukup tinggi.

Lokasi mitra adalah masyarakat Desa Wunut Tangkisan, Kecamatan Bayan Kabupaten Purworejo. Masyarakat pedesaan di Desa Wunut Tangkisan Kec.Bayan,Kabupaten Purworejo pada umumnya, berprofesi sebagai petani juga merangkap sebagai peternak.bTernak yang biasa dipelihara masyarakat Desa Wunut Tangkisan Kec.Bayan Kabupaten Purworejo adalah sapi, kambing, dan ayam. Berdasarkan data BPS
Kabupaten Purworejo tahun 2013, kecamatan Bayan memiliki jumlah sapi potong 1002 ekor dan menduduki lima besar di kabupaten Purworejo.

Pada Dukuh Wunut Desa Tangkisan Bayan Purworejo terdapat kelompok ternak "Bina Lestari" yang berada pada lokasi dukuh yang sama. Secara geografis Unit Kelompok Ternak "Bina Lestari" merupakan wilayah yang terletak di pesisir Samudera Hindia di bagian selatan Pulau Jawa pada koordinat $7^{\circ} 32^{\prime}$ LS sampai dengan $7^{\circ} 54^{\prime}$ LS dan $109^{\circ} 47^{\prime} 28^{\prime \prime}$ BT sampai dengan $110^{\circ} 8^{\prime} 20^{\prime \prime}$ BT sesuai dengan peta administrasi Kabupaten Purworejo pada Gambar 1. Posisi astronomis tersebut menunjukkan bahwa Kabupaten Purworejo terletak pada daerah beriklim tropis basah, yang dicirikan dengan curah hujan dan suhu yang tinggi. Kisaran suhu pada daerah ini berkisar antara $16,67^{\circ} \mathrm{C}$ $30,87^{\circ} \mathrm{C}$ dengan kelembaban yang tinggi pula berkisar antara $70 \%$ hingga $90 \%$.

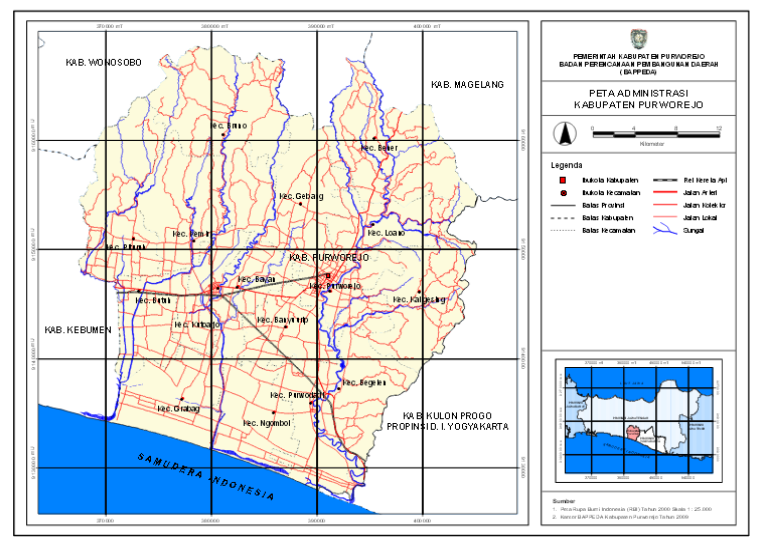

Gambar 1. Peta Lokasi Kelompok Ternak Bina Lestari

Kelompok ternak Bina Lestari terdiri dari 12 Kepala Keluarga dan mempunyai kandang dua tingkat dengan jumlah sapi 18 ekor. Kebersihan kandang sapi, sangat diperhatikan sehingga kotoran sapi nantinya dapat termanfaatkan dengan baik. Pembersihan rutin biasa dilakukan setiap hari,tiga kali sehari yaitu pagi, siang dan sore. Gambar 2 menunjukkan kondisi ternak sapi Bina Lestari 


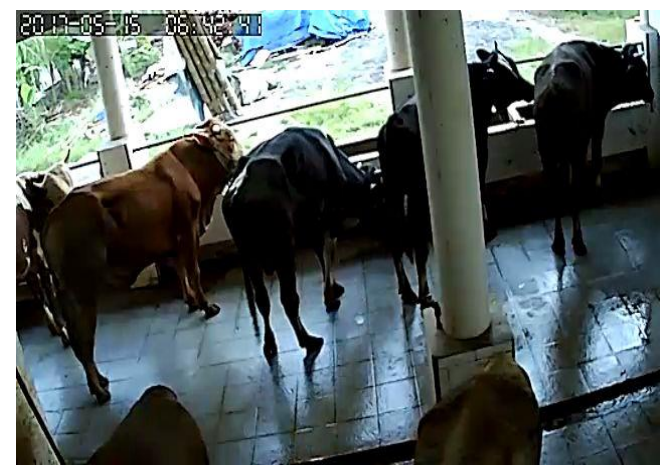

Gambar 2. Kondisi kandang sapi Bina Lestari

Saat ini telah terbangun satu unit biodigester dengan ukuran $8 \mathrm{~m}^{3}$ oleh kelompok ternak sapi Bina Lestari. Biogas yang dibuat berasal dari kotoran sapi ini telah membantu meringankan beban kebutuhan akan bahan bakar untuk memasak tanpa harus bergantung lagi sama tabung LPG. Biodigester tersebut hanya dapat dimanfaatkan untuk $7 \mathrm{KK}$ dari $12 \mathrm{KK}$ yang berada kelompok ternak. Pemanfaatan biogas hanya untuk $7 \mathrm{KK}$ yang berada di sebelah timur kandang, sedangkan masih ada 5 KK yang belum mendapatkan supply biogas seperti pada gambar 1.3. Limbah dari biodegester saat ini tidak dimanfaatkan sebagai pupuk, karena ketidakpahaman dari kelompok tersebut tentang bagaimana cara pengolahannya. Berdasarkan kondisi tersebut maka perlu dilakukan pengolahan limbah biodigester menjadi pupuk cair maupun padat.

Berdasarkan hal tersebut perlu dilakukan pengembangan untuk membangun biodigester agar warga yang belum mendapatkan supply biogas dapat teratasi. Permasalahan khusus yang dihadapi oleh mitra dalam hal ini adalah kelompok ternak Bina Lestari adalah bagaimana meningkatkan kapasitas biodigester agar semua kepala keluarga dapat memanfaatkan biogas.

Permasalahan prioritas yang dihadapi mitra dalam segi sosial, mutu layanan dan kehidupan bermasyarakat adalah masih ada 5 kepala keluarga (KK) yang belum mendapatkan supply biogas untuk memasak sehingga keempat KK masih mengkonsumsi LPG tabung $3 \mathrm{Kg}$ dan juga masih menggunakan kayu bakar. Kelima KK tersebut berharap pembangunan biodigester tambahan untuk melayani kebutuhan mereka. Limbah biodigester dapat dimanfaatkan untuk diolah menjadi pupuk. Selain sebagai peternak sapi, warga kelompok tani bina lestari juga memiliki lahan pertanian yang saat ini di tanami padi

\section{METODE}

Permasalahan yang dihadapi oleh kelompok ternak bina lestari adalah terdapat $5 \mathrm{KK}$ dari $12 \mathrm{KK}$ yang belum mendapatkan bionergi atau biogas yang dihasilkan oleh biodigester yang sudah ada dalam kelompok ternak tersebut. Solusi yang ditawarkan untuk menghadapi permasalahan tersebut adalah melakukan perancangan dan pembuatan biodigester baru dengan kapasitas $12 \mathrm{~m}^{3}$ yang mampu melayani $5 \mathrm{KK}$ yang belum mendapatkan energi tersebut

Tahapan atau langkah-langkah dalam melaksanakan solusi yang ditawarkan untuk mengatasi atas permasalahan yang dihadapi mitra ditunjukkan pada Gambar 3.

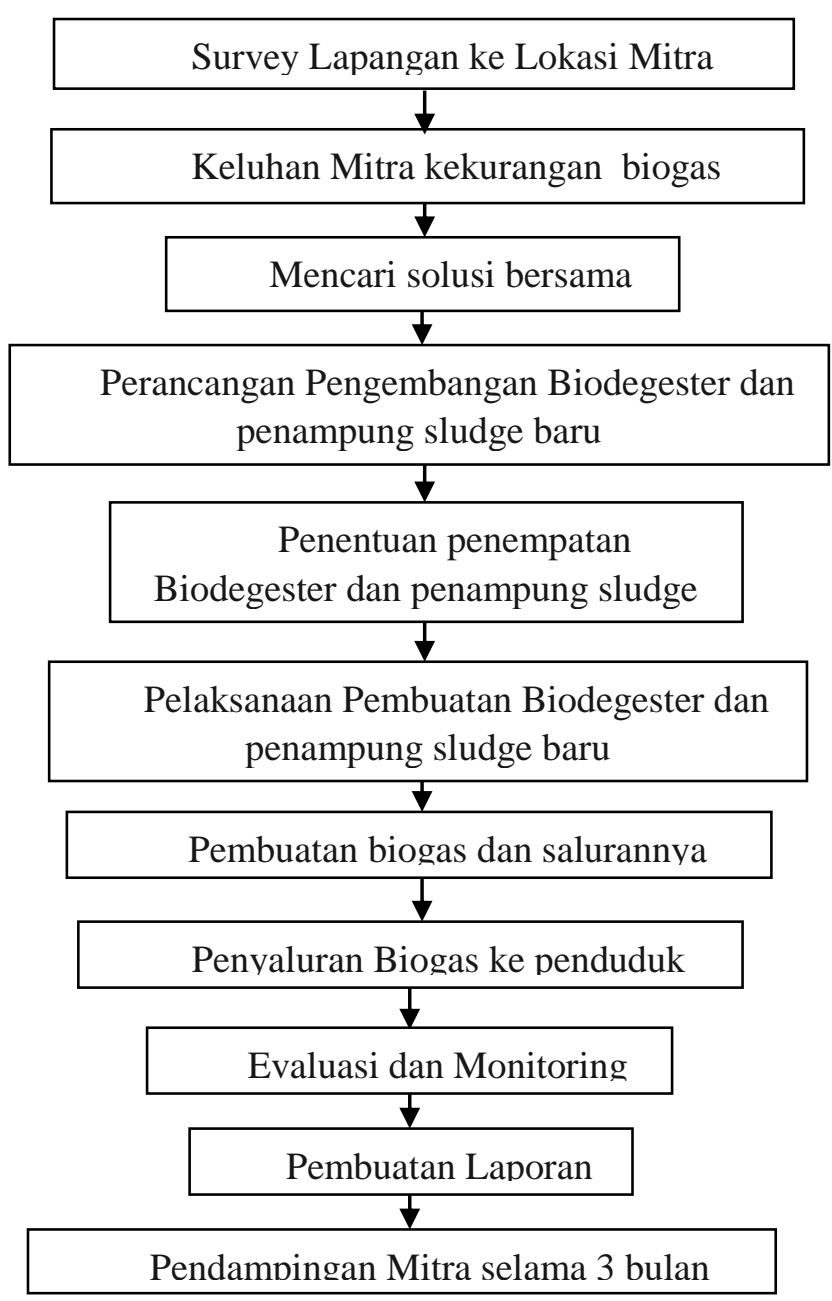


Gambar 3.Tahapan Pelaksanaan

Pengembangan Biodegester

Metode pendekatan yang ditawarkan untuk menyelesaikan persoalan mitra yang telah disepakati bersama antara lain (1) perancangan biodigester baru dengan kapasitas $12 \mathrm{~m}^{3}$ untuk melayani warga kelompok ternak Bina Lestari yang belum mendapatkan biogas dari pembangunan biodigester yang telah ada, (2) menentukan lokasi pembangunan biodigester dan penampungan sludge, (3) pelaksanaan pembangunan biodigester dan penampungan sludge (4) pembuatan dan penyaluran biogas ke warga

\section{HASIL DAN PEMBAHASAN}

Solusi yang ditawarkan untuk menyelesaikan permasalahan mitra adalah membangun biodigester tambahan dengan kapasitas $12 \mathrm{~m}^{3}$. Kapasitas tersebut dapat digunakan untuk 12 KK. Jadi selain untuk melayani $5 \mathrm{KK}$ yang belum mendapat supply, sisanya biogas dapat dijual ke warga lain sehingga menambah pendapatan bagi kelompok ternak Bina Lestari. Pada saat ini akan dikembangkan pengemasan bioenergi atau biogas tersebut dalam tabung gas seperti tabung gas $3 \mathrm{~kg}$ yang dijual dipasaran. Tabung gas tersebut akan dijual ke desa tetangga

\section{Layout Biodigester kapasitas $12 \mathbf{m}^{3}$}

Layout pembangunan biodigester dengan kapasitas $12 \mathrm{~m}^{3}$ ditunjukkkan pada gambar 4 . Ukuran diameter penampungan atau biodigester sebesar $34 \mathrm{~m}$ dengan tinggi $18 \mathrm{~m}$.

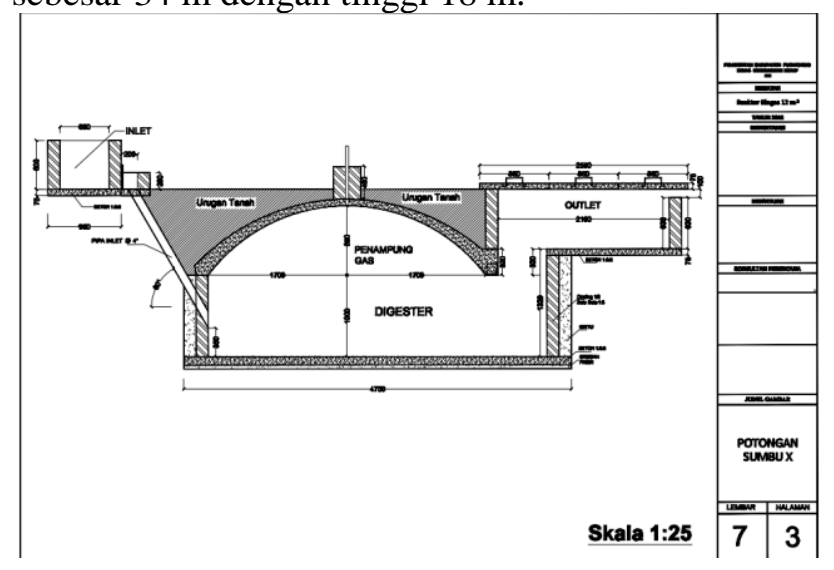

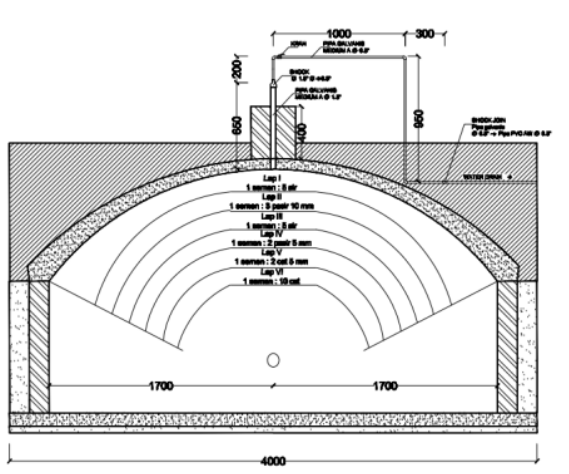

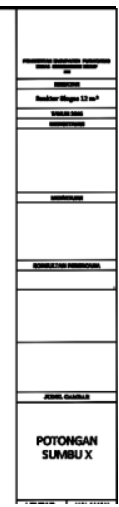

Gambar 4. Layout pembangunan Biodigester

\section{Proses Pembuatan Biodigester}

Proses pembuatan biodigester dimulai dari tanggal 16 Juli 2019 sampai dengan 30 Juli 2019. Proses pembuatan ditunjukkan pada Gambar 5.

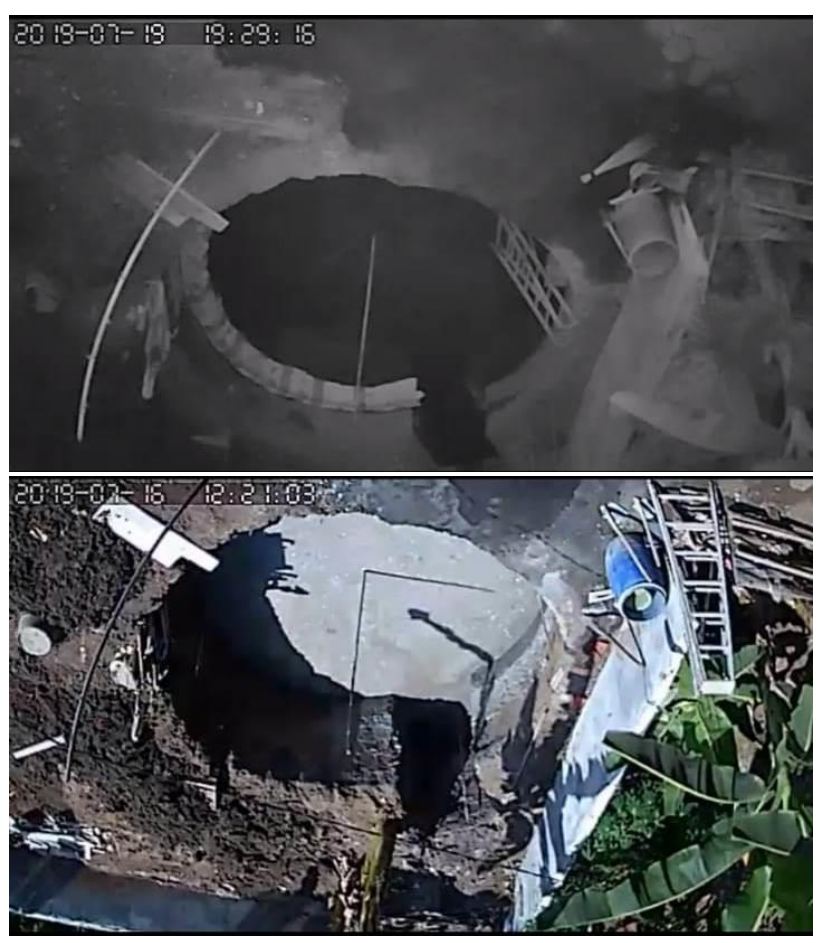




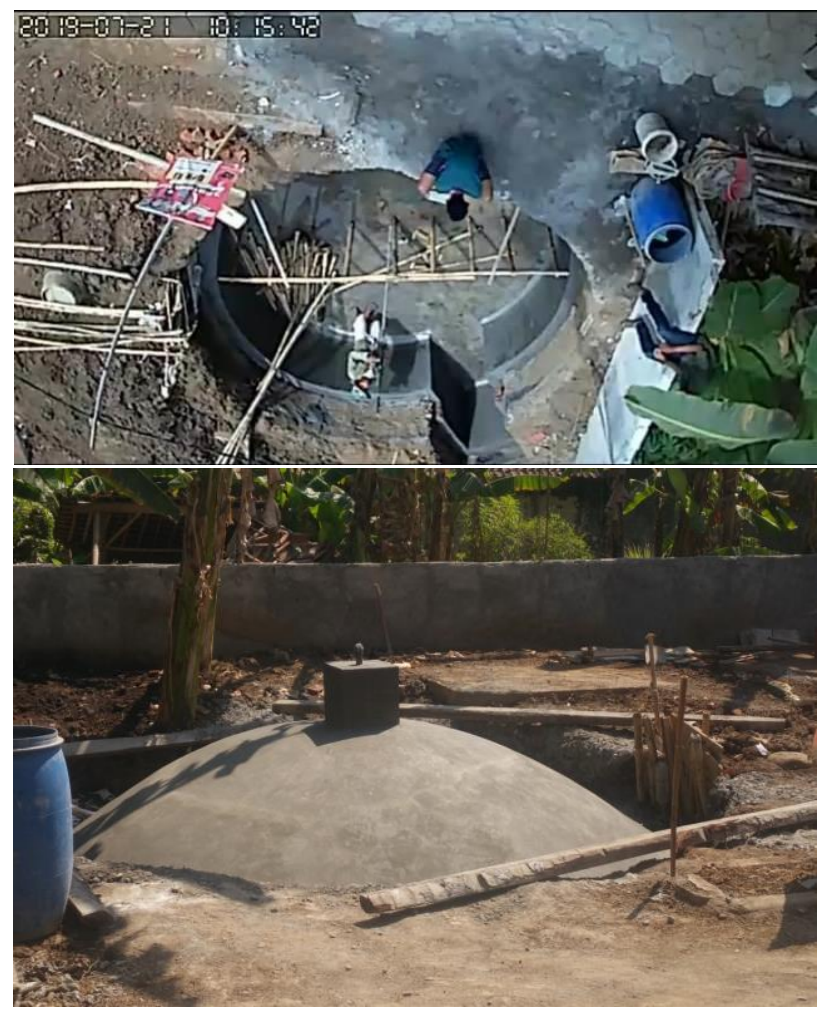

Gambar 5. Pembangunan dan pembuatan Biodigester

Hasil biogas dimanfaatkan untuk memasak dan juga untuk lampu penerangan di sekitar kandang, seperti terlihat pada Gambar 6.

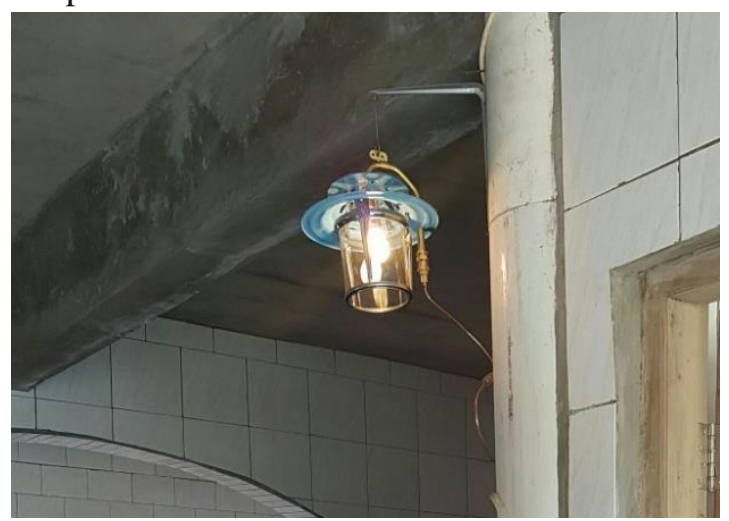

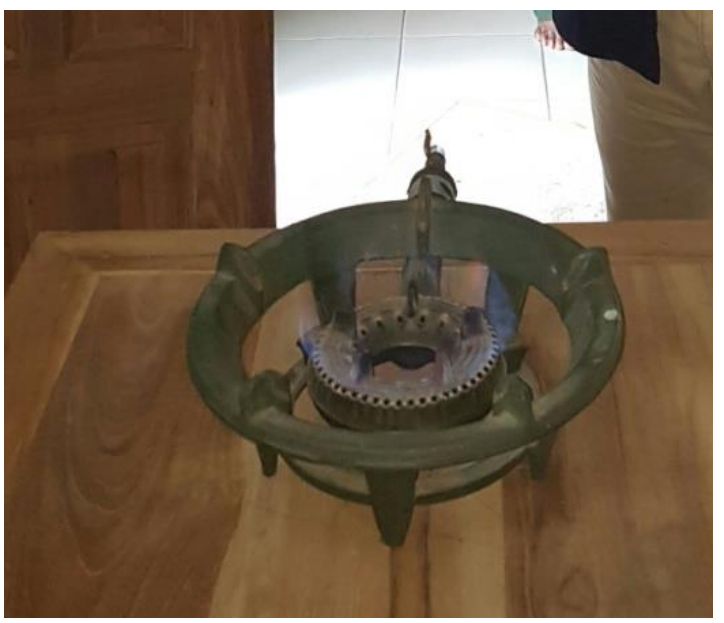

Gambar 6 Lampu penerangan dan kompor kandang

\section{KESIMPULAN}

Pengabdian PKM Bioenergi Dukuh Wunut Desa Tangkisan Kec Bayan Purworejo telah dijalankan dengan baik dan tanpa halangan yang berarti. Dengan kerjasama tim pengabdian yang baik dan peran serta aktif dari mitra atau kelompok ternak bina lestari dalam kegiatan pengabdian ini maka semuanya telah berjalan sesuai yang diharapkan dan harapannya dapat memberikan manfaat bagi mitra pengabdian masyarakat dalam keberlanjutan pembuatan biodigester. Pengabdian yang kami lakukan ini telah sampai pada tahapan dilaksanakannya pembuatan dan pengujian biodigester.

\section{UCAPAN TERIMAKASIH}

Ucapan terimakasih disampaikan kepada RISTEKDIKTI yang telah memberikan pendanaan terhadap kegiatan Pengabdian kepada masyarakat ini melalui Program Kemitraan Masyarakat.

\section{REFERENSI}

Badan Pusat Statistik Kabupaten Purworejo, https://purworejokab.bps.go.id/ linkTableDinamis/view/id/46, (diakses 5 Juni 2017)

Dodik Prasetyo R, Suryo Widodo, M.Muslimin Ilham, 2016, Pengembangan Biodigester Berkapasitas 200 Liter Untuk Pembuatan 
Biogas Dari Kotoran Sapi, Skripsi, UN PGRI Kediri

Deublein D dan Steinhauser A. 2008. Biogas from Waste an Renewable Resources. WileyVCH Verlag GmbH \& Co. Weinheim.Jerman.

Ismaila O Alabi, Kamorudeen A Olaiya , Mudasiru A Aderonmu, Teslim A Adio, Mutiu O Kareem , Fatai O Raji, 2016, Comparative Analysis of Gases Obtained From A BioDigester Using Different Waste Media, Journal of Scientific and Engineering Research, 2016, 3(3):266-272
Horikawa. 2004. Chemical Absorbtion Of H2S For Biogas Purification, Vol.21 No. 03 p. 415422.

Houdkova L., J. Boran., J. Pecek dan P. Sumpela. 2008. Biogas - A Renewable Source of Energy. Journal of Thermal Science 12(4): 27-33.

Saija, R., (2009) "Biogas Composition and Upgrading to Biomethane" JYVASKYLA Studies in Biological and Environmental Science 202, pp. 9-15. 